\title{
Progestagen-concentrating cells in the brain, uterus, vagina and mammary glands of the galago (Galago senegalensis)
}

\author{
Maryvonne Warembourg \\ U 156 INSERM, Place de Verdun, 59045 Lille Cedex, France
}

\begin{abstract}
Summary. Progestagen-concentrating cells were localized in the oestrogen-primed ovariectomized galago by radioautography after injection of $\left[{ }^{3} \mathrm{H}\right]$ promegestone (R5020). In the brain, radioactivity was concentrated in the nuclei of neurones in the preoptic region and in the mediobasal hypothalamus. Labelled cells were also observed in the anterior pituitary. In the uterus (uterine horns and cervix), the muscle and stromal cells showed greater labelling than did the glandular and luminal epithelia. Labelled cells were present in the different cell layers of the vagina. The majority of glandular epithelial cells of the mammary glands exhibited a high degree of labelling. Pretreatment with an excess of unlabelled promegestone but not with an excess of nonradioactive testosterone reduced the nuclear concentration of radioactivity in these target tissues. These results show that there are no major differences in the distribution of progestagen-concentrating cells in rodents and galago.
\end{abstract}

\section{Introduction}

Cytoplasmic and nuclear progestagen receptors have been identified in the central nervous system and in the uterus of the rat (Kato \& Onouchi, 1977; Moguilewsky \& Raynaud, 1977, 1979a, b; Kato, Onouchi \& Okinaga, 1978; Vu Hai \& Milgrom, 1978a, b; MacLusky \& McEwen, 1978, 1980; Blaustein \& Wade, 1978; Seiki, Haruki, Imanishi \& Enomoto, 1979; Haruki, Seiki \& Imanishi, 1980) and of the monkey (MacLusky, Lieberburg, Krey \& McEwen, 1980; Garris, Billiar, Takaoka, White \& Little, 1981). The concentration of these receptors increased after oestrogen treatment in the hypothalamus, pituitary and uterus. Progestagen binding sites have also been demonstrated in normal mammary tissue of mice (Haslam \& Shyamala, 1979) and their relative distribution has been biochemically studied in tissue components (Haslam \& Shyamala, 1981).

In these reports of progestagen binding in target tissues, promegestone, a potent synthetic progestagen, was used because it presents certain distinct advantages over progesterone. It binds with greater affinity to progestagen receptors and forms a more slowly dissociating complex with the progesterone receptor than does progesterone. Moreover, promegestone does not bind to corticosteroid-binding globulin (Philibert \& Raynaud, 1974; Raynaud, 1977).

We have previously described the precise anatomical distribution of receptor sites for progestagens in the brain and the genital tract of the guinea-pig after injection of $\left[{ }^{3} \mathrm{H}\right]$ progesterone (Warembourg \& Milgrom, 1971; Warembourg, 1974, 1978a) and of the rat after injection of $\left[{ }^{3} \mathrm{H}\right]-$ promegestone (Warembourg, 1978b, c). We have now extended our research to the galago, a prosimian primate. 


\section{Materials and Methods}

Five mature female galagos (Galago senegalensis) weighing about $250 \mathrm{~g}$ were obtained from Primate Imports Corporation, New York, U.S.A. The animals were ovariectomized 8-15 days before use. For the 3 days before being killed each animal was given a daily s.c. injection of $10 \mu \mathrm{g}$ oestradiol (Roussel-Uclaf, Romainville, France) in $0.2 \mathrm{ml}$ sesame oil. At $24 \mathrm{~h}$ after the final injection, they were injected s.c. with $300 \mu \mathrm{Ci}\left[17 \alpha-\right.$ methyl $\left.{ }^{3} \mathrm{H}\right]$ promegestone $(17 \alpha, 21$-dimethyl-19-norpregna-4, 9diene-3,20-dione) in $0.25 \mathrm{ml}$ saline $(0.9 \% \mathrm{NaCl}$ solution $\mathrm{w} / \mathrm{v})$ and $0.05 \mathrm{ml}$ ethanol. At $15 \mathrm{~min}$ before the isotope injection, 2 of the 5 animals were injected subcutaneously with a suspension of $1 \mathrm{mg}$ unlabelled promegestone or a suspension of $1 \mathrm{mg}$ unlabelled testosterone (Roussel-Uclaf). Unlabelled and tritiated promegestone (sp. act. $85 \mathrm{Ci} / \mathrm{mmol}$ ) were obtained from New England Nuclear Corporation, Boston, Massachusetts. The galagos were killed by decapitation 30 min after the injection of $\left[{ }^{3} \mathrm{H}\right]$ promegestone. The brains, pituitaries, uteri (uterine horns and cervix), vaginas and mammary glands were rapidly removed, cut into small pieces and frozen immediately in isopentane cooled with liquid nitrogen.

The details of the radioautographic procedure have been described elsewhere (Warembourg 1974, 1976). Briefly, the tissue blocks were cut into $8 \mu \mathrm{m}$ thick sections in a cryostat (W.K.F. Brandau, West Germany) at $-20^{\circ} \mathrm{C}$ in a darkroom. Frontal and sagittal sections of the brain were made. The frozen sections were then mounted directly on slides coated with Kodak AR 10 emulsion. After radioautographic exposure at $-15^{\circ} \mathrm{C}$ for $117-135$ days the slides were photographically processed and the sections were stained with methyl green-pyronin.

\section{Results}

\section{Brain}

Radioautograms obtained after injection of $\left[{ }^{3} \mathrm{H}\right]$ promegestone showed a nuclear concentration of radioactivity in certain cells of the brain. All sections from the anterior telencephalon to the mesencephalon were systematically scanned and the distribution of progestagen-concentrating cells is depicted in Text-fig. 1. The radioactivity was concentrated in nuclei of neurones of the preoptic area and the mediobasal hypothalamus. In the preoptic region, labelled cells were seen in the nucleus preopticus pars suprachiasmatica surrounding the optic recess. Moderate to heavily labelled cells were observed in the nucleus preopticus periventricularis (Pl. 1, Fig. 1); they were distributed throughout its extent in a column on each side of the midline. Weakly labelled cells were found sparsely distributed in the nucleus preopticus lateralis. At a more anterior level, a few scattered neurones were labelled in the region of the vascular organ of the lamina terminalis. Within the hypothalamus, high concentrations of labelled cells with the greatest intensity of labelling per cell occurred in the basal and lateral portions of the nucleus ventralis hypothalami (Pl. 1, Fig. 2). The nucleus arcuatus contained labelled cells which extended particularly throughout the ventral part of the nucleus from its most rostral to its most caudal portion (Pl. 1, Figs 3 \& 4). More caudally, the nucleus premamillaris and the mamillary complex were essentially unlabelled.

Under the conditions of the experiment no labelled cells were found in the forebrain, cortex, hippocampus, amygdala and midbrain.

\section{Pituitary}

A few cell nuclei were labelled in the anterior pituitary. These cells, with varied amounts of silver grains, were distributed throughout the whole anterior lobe. The histological stain employed did not permit precise determination of the cell types. 
PLATE 1
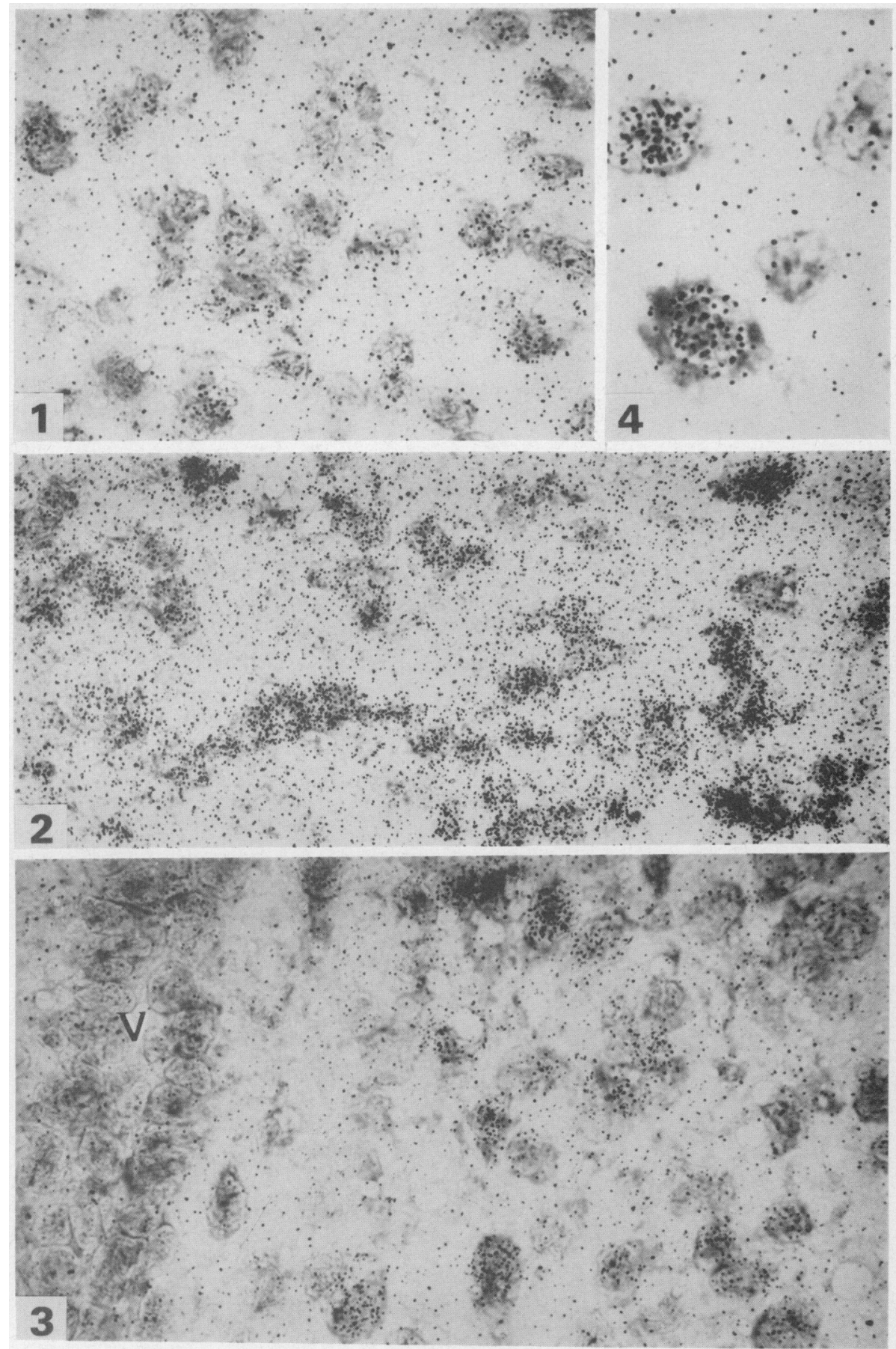

Radioautograms of various brain regions of a galago injected with $\left[{ }^{3} \mathrm{H}\right]$ promegestone.

Fig. 1. The nucleus periventricularis preopticus. $\times 660$.

Fig. 2. The nucleus ventromedialis pars lateralis. $\times 530$.

Fig. 3. The nucleus arcuatus, $V=$ third ventricle. $\times 660$.

Fig. 4. The same region as Fig. 3, showing the silver grains concentrated over the cell nuclei. $\times 1320$. 




Figs 5 and 6. Radioautograms of the endometrium, showing the labelling of the stromal cells (Figs 5 and 6), the glandular epithelium (Fig. 5) and the luminal epithelium (Fig. 6). $\times 660$.

Fig. 7. Radioautogram of the myometrium. There is a concentration of radioactivity in the nuclei of the muscular fibres of the inner layer. $\times 530$. 

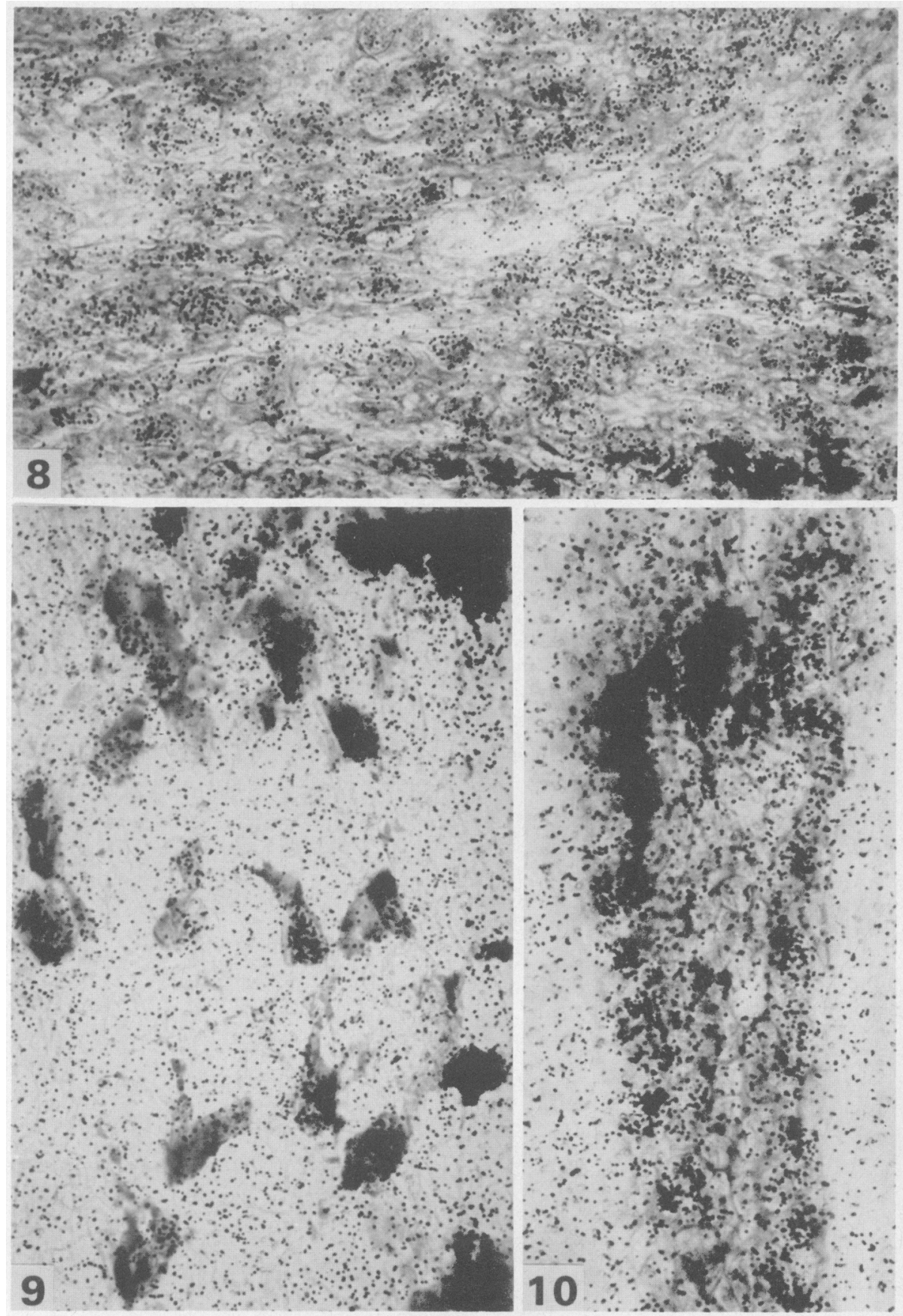

Fig. 8. Radioautogram of the muscularis of the vagina. There is a concentration of radioactivity in the nuclei of the fibres. $\times 660$.

Fig. 9. Radioautogram of the vaginal mucosa; there is considerable labelling of connective tissue cells. $\times 825$.

Fig. 10. Radioautogram of the glandular epithelium of the mammary gland. $\times 825$. 

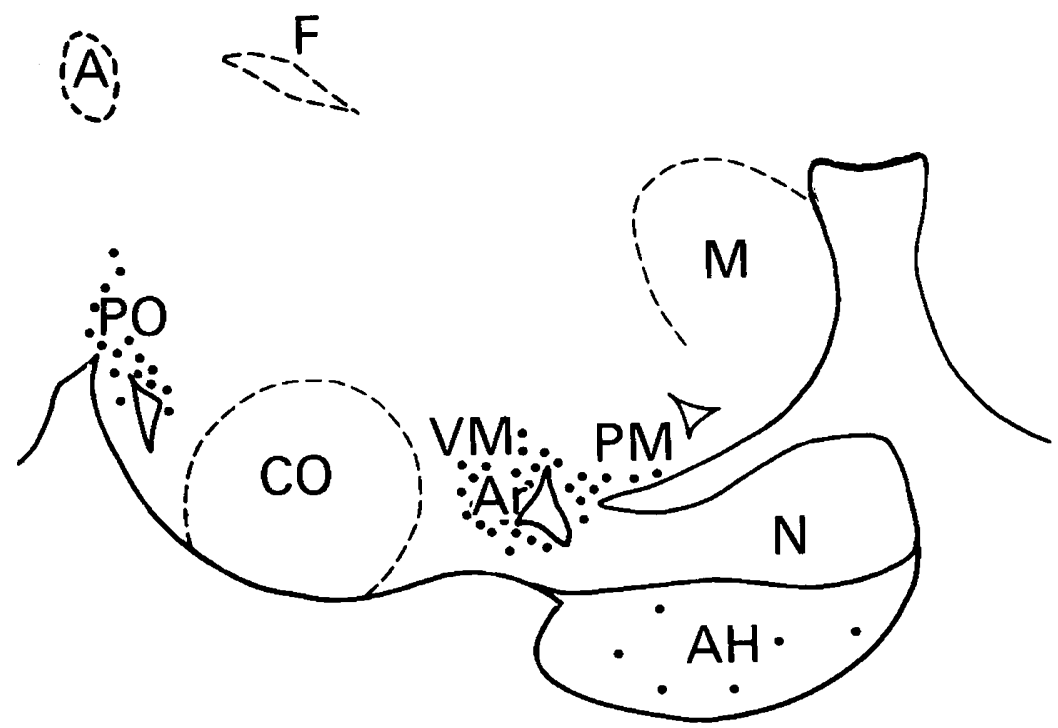

Text-fig. 1. Schematic distribution of labelled cells (represented by dots) on a sagittal section of the hypothalamus and pituitary of the oestrogen-primed ovariectomized galago treated with $\left[{ }^{3} \mathrm{H}\right.$ ]promegestone. A, commissura anterior; $\mathrm{AH}$, adenohypophysis; $\mathrm{Ar}, \mathrm{n}$. arcuatus; $\mathrm{CO}$, chiasma opticum; F, fornix; M, n. mamillaris; N, neural lobe; PM, n. premamillaris ventralis; PO, n. preopticus medialis; VM, n. ventromedialis hypothalami.

\section{Uterus (uterine horns and cervix)}

Although radioactivity existed in the different structures of the endometrium, nuclear concentration of radioactive material was more important in the stromal cells (Pl. 2, Figs 5 \& 6) than in the glandular (Pl. 2, Fig. 5) and luminal (Pl. 2, Fig. 6) epithelial cells which were lightly labelled. Whatever the observed area of the stroma there were no apparent variations in the number of the labelled cells and in the intensity of the labelling. The inner and outer layers of the myometrium contained a large number of labelled cells; the silver grain density was very high in the nuclei of these cells (P1. 2, Fig. 7).

\section{Vagina}

Silver grains were observed in cell nuclei of the bundles of smooth muscle where the inner circular muscle cells are interwoven with the outer longitudinal cells (P1. 3, Fig. 8). In the connective tissue of the lamina propria, subjacent to the vaginal epithelium, most scattered cells were heavily labelled (PI. 3, Fig. 9). Radioactivity was found in the stratified squamous epithelium, especially in the nuclei of the basal layer with a rapid decrease from the basal region to the surface.

\section{Mammary glands}

Although silver grains were seen distributed diffusely over different structures, most of the radioactivity was concentrated in nuclei of the epithelial cells of the ducts (P1. 3, Fig. 10). The basal cells of the sparse epithelium showed more labelling than the superficial cells. In our radioautograms, no selective subcellular retention of radioactivity was noted in the connective and adipose tissues. However, in methyl green-pyronin-stained cryostat sections it was difficult to identify the connective tissue precisely because of the predominance of fat cells. Therefore involvement of these cells in concentrating hormone cannot be definitely excluded. 


\section{Competition experiments}

After preinjection of an excess of unlabelled promegestone there was a clearly displaceable nuclear concentration of radioactivity in the cells of the above tissues. On the other hand, in the presence of non-radioactive testosterone no consistent change was observed in the nuclear labelling of hypothalamic regions and cell types of the genital tract.

\section{Discussion}

The present radioautographic data describe the topographical distribution of progestagen target cells obtained with $\left[{ }^{3} \mathrm{H}\right]$ promegestone. Since the nuclear uptake observed in these cells can be inhibited by simultaneous treatment with unlabelled promegestone but very much less so by testosterone, the results suggest that the radioactivity represented promegestone or a biologically active metabolite and that the capacity of these cells to bind hormone is limited.

In the brains of oestrogen-treated and ovariectomized animals, the mediobasal hypothalamus and the preoptic area were most heavily labelled. The uterine tissues showed varied degrees of uptake, with the glandular and luminal epithelial cells containing less label than the stromal cells and smooth muscle fibres. The pattern of progestagen uptake was very similar to the patterns seen in rodents, i.e. guinea-pig after $\left[{ }^{3} \mathrm{H}\right]$ progesterone injection (Warembourg \& Milgrom, 1971 ; Sar \& Stumpf, 1973, 1974; Warembourg, 1974, 1978a) and rat after $\left[{ }^{3} \mathrm{H}\right]$ promegestone injection (Warembourg, 1978b, c). This localization of progestagen receptors corresponds well to results, obtained with biochemical techniques, which showed that after oestrogen treatment progestagen receptor concentrations rise in the mediobasal hypothalamus, preoptic area, pituitary and uterus but not in the amygdala, hippocampus or the cortex (Blaustein \& Wade, 1978; MacLusky \& McEwen, 1978, 1980; Moguilewsky \& Raynaud, 1979a). In the last 3 regions the receptors are present at levels which are not affected by oestrogen treatment. It is therefore possible that progestagen-binding sites in extrahypothalamic tissues exist at low concentrations below the sensitivity of our radioautographic technique and cannot be precisely detected by this means.

Progestagen target cells are located in some of the same nervous regions as those containing oestradiol-concentrating neurones, particularly the mediobasal hypothalamus and preoptic area, as observed in the squirrel monkey (Warembourg, 1977). The rostral distribution of progestagen target cells also overlaps partly with the location of LH-RH secreting neurones in the galago (Barry, 1980). Based on these observations, progestagen-binding sites are localized in key neuronal regions implicated in the control of gonadotrophin secretion and of sexual behaviour.

High concentrations of radioactivity were localized in the glandular epithelial cells of the mammary glands. This agrees well with binding studies, using $\left[{ }^{3} \mathrm{H}\right]$ promegestone in the normal mouse mammary gland, of Haslam \& Shyamala $(1979,1981)$ who report that most of the progesterone receptors are present only in the glandular epithelium and that the oestrogenic regulation of these receptors appears to be restricted to the epithelial component. It is known that the effect of oestrogen and progestagen is important in the regulation of epithelial cell proliferation and the differentiation of the mammary tissue.

This work was supported by the I.N.S.E.R.M.

\section{References}

Barry, J. (1980) Immunofluorescence study of LRHproducing neurons in Prosimians (Tupaia and Galago). Cell Tissue Res. 206, 355-365.
Blaustein, J.D. \& Wade, G.N. (1978) Progestin binding by brain and pituitary cell nuclei and female rat sexual behavior. Brain Res. 140, 360-367. 
Garris, D.R., Billiar, R.B., Takaoka, Y., White, R.J. \& Little, B. (1981) In situ estradiol and progestin (R 5020) localization in the vascularly separated and isolated hypothalamus of the rhesus monkey. Neuroendocrinology 32, 202-208.

Haruki, Y., Seiki, K. \& Imanishi, Y. (1980) Specific progestin binding in vitro by anterior pituitary and brain tissues of male rats. Endocr. jap. 27, 439-446.

Haslam, S.Z. \& Shyamala, G. (1979) Progesterone receptors in normal mammary glands of mice: characterization and relationship to development. Endocrinology 105, 786-795.

Haslam, S.Z. \& Shyamala, G. (1981) Relative distribution of estrogen and progesterone receptors among the epithelial, adipose and connective tissue components of the normal mammary gland. Endocrinology 108, 825-830.

Kato, J. \& Onouchi, T. (1977) Specific progesterone receptors in the hypothalamus and anterior hypophysis of the rat. Endocrinology 101, 920-928.

Kato, J., Onouchi, T. \& Okinaga, S. (1978) Hypothalamic and hypophysial progesterone receptors: estrogenpriming effect, differential localization, $5 \alpha$-dihydroprogesterone binding and nuclear receptors. $J$. Steroid Biochem. 9, 419-427.

MacLusky, N.J. \& McEwen, B.S. (1978) Oestrogen modulates progestin receptor concentrations in some rat brain regions but not in others. Nature, Lond. 274, 276-278.

MacLusky, N.J. \& McEwen, B.S. (1980) Progestin receptors in rat brain : distribution and properties of cytoplasmic progestin-binding sites. Endocrinology 106, 192-202.

MacLusky, N.J., Lieberburg, I., Krey, L.C. \& McEwen, B.S. (1980) Progestin receptors in the brain and pituitary of the bonnet monkey (Macaca radiata): differences between the monkey and the rat in the distribution of progestin receptors. Endocrinology 106, 185-191.

Moguilewsky, M. \& Raynaud, J.P. (1977) Progestin binding sites in the rat hypothalamus, pituitary and uterus. Steroids 30, 99-109.

Moguilewsky, M. \& Raynaud, J.P. (1979a) Estrogensensitive progestin-binding sites in the female rat brain and pituitary. Brain Res. 164, 165-175.

Moguilewsky, M. \& Raynaud, J.P. (1979b) The relevance of hypothalamic and hypophyseal progestin receptor regulation in the induction and inhibition of sexual behavior in the female rat. Endocrinology 105, 516522.
Philibert, D. \& Raynaud, J.P. (1974) Progesterone binding in the immature mouse and rat uterus. Steroids 22, 89-98.

Raynaud, J.P. (1977) R5020, a tag for the progestin receptor. In Progesterone Receptors in Normal and Neoplastic Tissues, pp. 9-21. Eds W. L. McGuire, J. P. Raynaud \& E. E. Baulieu. Raven Press, New York.

Sar, M. \& Stumpf, W.E. (1973) Neurons of the hypothalamus concentrate ${ }^{3} \mathrm{H}$ progesterone or its metabolites. Science, N.Y. 182, 1266-1267.

Sar, M. \& Stumpf, W.E. (1974) Cellular and subcellular localization of ${ }^{3} \mathrm{H}$-progesterone or its metabolites in the oviduct, uterus, vagina and liver of the guinea pig. Endocrinology 94, 1116-1125.

Seiki, K., Haruki, Y., Imanishi, Y. \& Enomoto, T. (1979) Progestin binding in vitro by the brain cell nuclei of ovariectomized oestrogen-primed-rats. J. Endocr. 82, 347-361.

Vu Hai, M.T. \& Milgrom, E. (1978a) Characterization and assay of the progesterone receptor in rat uterine cytosol. J. Endocr. 76, 21-31.

Vu Hai, M.T. \& Milgrom, E. (1978b) Characterization and assay of the progesterone receptor in rat uterine nuclei. J. Endocr. 76, 33-41.

Warembourg, M. (1974) Radioautographic study of the guinea pig uterus after injection and incubation with ${ }^{3} \mathrm{H}$-progesterone. Endocrinology 94, 665-670.

Warembourg, M. (1976) Detection of diffusible substances. J. Microscopie Biol. cell. 27, 277-280.

Warembourg, M. (1977) Topographical distribution of estrogen-concentrating cells in the brain and pituitary of the squirrel monkey. Neuroscience Letters $\mathbf{5}$, $315-319$.

Warembourg, M. (1978a) Radioautographic study of the brain and pituitary after ${ }^{3} \mathrm{H}$-progesterone injection into estrogen-primed ovariectomized guinea pigs. Neuroscience Letters 7, 1-5.

Warembourg, M. (1978b) Radioautographic study of the rat brain, uterus and vagina after ${ }^{3}$ HR 5020 injection. Mol. Cell. Endocr. 12, 67-79.

Warembourg, M. (1978c) Uptake of ${ }^{3} \mathrm{H}$ labeled synthetic progestin by rat brain and pituitary. A radioautographic study. Neuroscience Letters 9, 329--332.

Warembourg, M. \& Milgrom, E. (1971) Etude radioautographique des sites de fixation de la progesterone ${ }^{3} \mathrm{H}$ au niveau de l'utérus de cobaye. $C$. $r$. hebd. Séanc. Acad. Sci., Paris D 273, 891-893.

Received 23 September 1982 